\author{
Teresa Mróz* \\ Ewa Katarzyna Czech* \\ Ewa Kowalewska-Borys ${ }^{* * *}$
}

\title{
Liability in Environmental Protection Regulations - Outline of the Issue in Polish Law - Part Two
}

1. Repressive Liability for Prohibited Acts Against the Environment

\subsection{Introductory issues}

Concern about ecological security and protection of natural environment constitute a public issue of great importance. The pertinent regulation of guarantee can be found in the article 74 of the Constitution of the

* Ph.D., Professor in the Civil Law Department at University of Bialystok.

** Ph.D., Prof. of University of Bialystok.

*** Ph.D., mgr.iur.comp. of University of Bonn. 
Teresa Mróz, Ewa Katarzyna Czech, Ewa Kowalewska-Borys

Republic of Poland ${ }^{1}$, according to which public authorities shall pursue policies ensuring the ecological security of current and future generations (section 1), and protection of the environment shall be their duty (section 2). In addition pursuant to sections 3 and 4 everyone shall have the right to be informed of the quality of the environment and its protection and public authorities shall support the activities of citizens to protect and improve the quality of the environment. In consideration of the above there is no doubt that the Polish legislator in order to ensure proper and effective environmental protection has shaped legal instruments providing efficient prosecuting in the wider sense in an interdisciplinary way. For the purpose, regulations of administrative, civil and penal law have been involved.

\subsection{Legal nature of liability for offences against the environment}

From the perspective of the penal law, legal liability for prohibited acts concerning environmental protection is repressive liability, as it combines liability for crime (criminal liability in the strict sense) regulated by articles 181-187 of the Polish Penal Code (hereinafter referred to as the PC) ${ }^{2}$ as well as liability for petty offence ${ }^{3}$, mainly regulated by the EPA and also by the Polish Code of Petty Offences (hereinafter referred to as the $\mathrm{CPO})^{4}$. Repressive liability is an expression of ruling state intervention, its power over certain social conditions, in this case in order to provide appropriate protection of natural environment. It is a special form of state's reaction to actions contravening certain legal norms, i.e. binding orders and prohibitions. Thus, it involves a repressive objective and functions

1 The Constitution of The Republic Of Poland of 2nd April, 1997; As published in Journal of Laws, No 78, item 483 with amendments.

2 The Act of 6 June 1997 - Penal Code, as published in Journal of Laws, No 88, item 553 with subsequent amendments.

3 In the sentence of 19 February 2004 (File No. P 48/06) the Constitutional Tribunal indicated that petty offense liability is of a repressive nature. Cf. the following rulings of Constitutional Tribunal: of 4 July 2002, File No. P 12/01, OTK ZU No. 4/A/2002, Item 50; of 3 November 2004 r., File No. K 18/03, OTK ZU No. 10/A/2004, Item 103; of 19 March 2007 r., File No. K 47/05, OTK ZU No. 3/A/2007, item 27.

4 The Act of 20 May 1971 - Code of Petty offenses, Journal of Laws, No. 12, item114 with subsequent amendments. 
Liability in Environmental Protection Regulations... - Part Two

of adjudicated punishments, being a retaliation to an act prohibited by law and, at the same time, expressing condemnation of the offender's act.

The same elements determine liability for crimes and petty offences, and those are, above all, the illegality of an act (article 1 Section 1 of the $\mathrm{CPO}$ ) and the fault (article 1 section 2 of the CPO). However, the gravity of crimes and petty offences as well as the level of social noxiousness of an act and as a result the extent of moral condemnation - which with regard to petty offences is slight - differ. Petty offences in comparison to crimes are dealt with evidently more leniently, which is proved by possible pain (article 1 section 1 of the CPO). Penalties for petty offences are less strict.

The subject of the analysis are petty offences against the environment regulated by the EPA. The issue of indicating who and under what circumstances is liable for a petty offence against the environment has a great significance. Liability for a petty offence cannot be limited only to one condition - it consists of several intertwined conditions. Liability for a petty offence means capacity to commit a socially harmful act prohibited by law binding at the time of committing it (article 1 section 1 of the CPO), which is a petty offence, combined with the necessity of taking negative consequences (i.e. penalty of arrest, term imprisonment, a fine up to PLN 5,000 or a reprimand, or other retributive punishment). It is understandable that the regulations provided in the EPA are not of a comprehensive nature and, as a result, they ought to be interpreted taking into consideration regulations of the Polish CPO. Among the most important elements of liability for petty offences there also are: capacity to commit an offence only by a natural individual who at the time of committing the offence is over 17 (article 8 of the CPO), and who the default can be assigned to (article 1 section 2 of the $\mathrm{CPO}$ ).

\subsection{Types of petty offences against the environment regulated in the Environmental Law Act}

Articles 329-360 of the EPA regulate types of petty offences against the environment forming the basis for repressive liability in substantive law. In general petty offences are a legal consequence of not submitting by the definite entities - private individuals only - to orders and prohibitions imposed by the EPA of 2007 or breaching other legal bans. The basic criminal sanction is a fine, whose amount is determined on the basis 
Teresa Mróz, Ewa Katarzyna Czech, Ewa Kowalewska-Borys

of the rule of article 24 section 1 of the CPO, i.e. from PLN 20 to 5,000. In particular cases the court ruling in the case of an offence against the environment can apply a penalty of arrest or imprisonment.

Pursuant to article 329 of the EPA, a natural person responsible for activities of the organisational entity which they represent and which is obligated by law and by an administrative decision to carry out measurements of emissions to the environment, does not collect, does not process the data and does not make it accessible without charge to the state environmental monitoring can be punished with a fine. The objective of the analysed regulation is criminalization of failing to fulfil the statutory duty concerning monitoring emissions into the environment, which is imposed on the organisational unit indicated in the provision of article 28 of the EPA.

Under the provision of article 330 of the EPA the investor, who, contrary to the statutory obligation, in the course of construction works does not provide protection of the environment, particularly conservation of soil, green spaces, natural landform, water relations, etc. in the area for works, is subject to liability for the petty offence punishable by a fine. It should be noted that the article with reference to the regulation of article 75 of the EPA has a very broad scope of duties, being a subject to the mandatory implementation, and resulting either from a building permit, or directly from the EPA. It should also be pointed out that the liability for this offence shall be imposed on the investor only and not, e.g. on a factual building works contractor.

Article 331 of the EPA determines the sanction in the form of a fine for the investor who, contrary to the statutory obligation, 30 days before commissioning does not inform the voivodeship environmental protection inspector on the planned date of commissioning of the construction works, a complex or installation of facilities or the date of completion of the installation. It should, however, be noted that the breach of the statutory duty of the investor regulated in article 76 section 4 of the EPA may be the basis of criminal liability under article 331 of the EPA and the basis of administrative liability under article 365 of the EPA. Therefore, it should be underlined that the same act of the same individual cannot constitute grounds for double liability, i.e. administrative and repressive one.

The provision of article 332 of the EPA provides liability and the imposition of fines for anyone who does not comply with the restrictions, injunctions or prohibitions, as defined in provincial governors' orders 
defining short-term action plans aimed at reducing the risk of exceeding limit values or alert levels for substances in the air in a particular area or at limiting the effects and duration of the outpass which has occurred. Considering the question of criminal liability within the scope of article 332 of the EPA, each time the court must carefully examine obligations specified in the applicable governor's order.

The provision of article 332 of the EPA regulates two petty offences. According to article 332 section 1 of the EPA, fines can be imposed to anyone who, while advertising or promoting a product, violates the obligation to provide information on: fuel consumption, emissions associated with use of the product, usage safe for the environment, disassembly, re-use or disposal of the product. According to article 332 section 2 of the EPA anyone who did not include information required by law (article 80 section 2 of the EPA), i.e. numerical signage, which allows identification of the product or the group of products, and their names in advertising or promotional material, can be punished with a fine. Such a vague and ambiguous way of determining the subject of criminal liability under article 332 of the EPA provides interpretative doubts, however, it should be noted that the perpetrator of this offence may be above all a producer of the advertised or otherwise promoted product.

According to article 333 of the EPA, a fine can be imposed on the subject using the environment, operating activities causing introducing substances into the air, who does not fulfil his obligation to carry out measurements of substance levels in the air or to store measurement results over the period required by an administrative decision. At this point, it should be indicated, however, that liability for a petty offence defined under article 333 of the EPA may, in fact, be assigned to a natural person responsible for fulfilling the obligations specified in a particular administrative decision.

Pursuant to article 334 of the EPA, liability for this offence shall be assigned to the operator who fails to comply with restrictions, injunctions or prohibitions concerning types or quality of fuels permitted for use within the province or its part, which are specified in a resolution of the regional council in order to prevent negative effects on the environment or on the monuments. The penalty for this offence is a fine, stipulated within the limits set out in article 24 section 1 of the CPO.

Article 336 of the EPA provides liability for failure to obtain an agreement on terms of rehabilitation in the form of an administrative decision or for exercising it against adopted arrangements (section 1) and for obstructing 
Teresa Mróz, Ewa Katarzyna Czech, Ewa Kowalewska-Borys

or hindering the rehabilitation conducted pursuant to the arrangements stated in an administrative decision issued by the starost (regarding the scope, method and starting and ending time of rehabilitation) (section 2 item 1), and for use of soil or ground in earthwork, not complying with the conditions set in the Order of the Minister of Justice of 5 September 2002 on standards for soil quality and ground quality standards (Journal of Laws, No 165, item 1355). The subject possessing the land under rehabilitation considered as a perpetrator of the offence will be punished with a fine.

In article 337 of the EPA sanctions in the form of fines for failure to comply with the obligation to conduct measurements of substances in the soil or ground, or for not storing their results for the required period are specified. This obligation results from an administrative decision issued by the starost to the landowner, in the area where soil or ground quality standards have been exceeded.

The provision of article 337a of the EPA provides liability for exceeding emission standards in the form of permissible noise levels. The basis for determining the permissible noise level will be the final decision of an environmental protection authority set on the basis of their own measurements, measurements made by the voivodeship environmental protection inspector or measurements made by an entity responsible for their conduct. While the penalty for committing this petty offence will be an alternative penalty of arrest, the penalty of imprisonment or a fine. The rules governing application of these penalties are provided in article 19 of the COP regarding the penalty of arrest which may be applied for the period from 5 to 30 days, article 20 section 1 of COP in relation to the penalty of imprisonment, which may be imposed for one month, and article 24 section 1 of the COP in relation to fines that may be imposed for the amount from PLN 20 to 5,000.

Article 338 of the EPA penalizes violation of provisions contained in the resolution of the county council concerning introduction of restrictions or prohibitions on use of vessels or some of their types on certain surface bodies of waters of standing and running waters, if it is necessary to ensure adequate acoustic conditions in areas intended for recreational purposes. The penalty for violating this provision is a fine.

Article 338 a of the EPA regulates liability of the operator and user for failure to perform measurements of electromagnetic fields in the environment of devices that emit electromagnetic fields, which are undertakings that may significantly affect the environment. These projects 
Liability in Environmental Protection Regulations... - Part Two

are defined in the Regulation of the Council of Ministers of 9 November 2004 on the types of projects that may significantly affect the environment and detailed conditions for qualifying projects to an environmental impact assessment (Journal of Laws, No 257, item 2573, with subsequent amendments). However, the rules and procedures for the measurement of electromagnetic fields in the environment have been normalized in the Order of Minister of Environment of 30 October 2003 on permissible levels of electromagnetic fields in the environment and ways to meet the validation of these measurements (Journal of Laws, No 192, item1883). Punishment for the offence may take the form of an alternative penalty of arrest, a penalty of imprisonment and a fine, applied on the terms and in the amount specified in articles 19,20 section 1,24 section 1 of the CPO.

Article 339 section 1 of the EPA introduces the sanction for not complying with the standards of a so-called common or ordinary use of the environment which does not require obtaining an appropriate permit for introducing substances or energy to the environment. The permissible emission standards have been specified in the Order of Minister of Environment of 20 December 2005 on standards concerning emissions from installations (Journal of Laws, No 260, item 2181, with subsequent amendments). The penalty for this offence is a fine. Section 2 of article 339 of the EPA also defines a sanction in the form of a fine for non-compliance with requirements for the proper operation of a plant or equipment requiring an authorization indicated in the above cited Order of the Minister of Environment of 2005 (section 2 item 1) and non-compliance with emission standards set for installations requiring a permit for use of the environment in case of a failure due to disruptions in technological processes and technical applications in the operation of installations or device.

Article 340 section 1 and 2 of the EPA provides a fine for noncompliance with measurement obligations or not archiving results of the measurements of emission and the amount of water taken from a newly constructed or substantially modified installation.

The provision of article 341 of the EPA determines liability for not submitting measurement results to an environmental protection authority and to the voivodeship environmental protection inspector, if they are of particular importance due to the need for systematic monitoring of emissions or other conditions of use of the environment.

Pursuant to article 342 of the EPA, a subject who, in spite of legal obligation, does not report information concerning the operation of an 
Teresa Mróz, Ewa Katarzyna Czech, Ewa Kowalewska-Borys

installation specified in the Order of the Minister of Environment of 2005, regardless of circumstances, whether it has a negative impact on the environment or not, or who operates the installation contrary to the submitted information (section 1), as well as one who operates the installation despite an objection of the authority competent to accept the application (section 2) - is punishable with a fine.

The provision of article 343 of the EPA provides the basis for liability of a subject that infringes a ban on use of amplifying equipment or installations in public city areas, in built-up areas and areas intended for recreational purposes (section 1). In turn, in accordance with article 343 section 2 of the EPA, a user of the environment and not complying with restrictions, injunctions or prohibitions determined in a resolution of the municipal council and regarding the time of the installation operation or use of devices emitting noise, is punishable with a fine.

According to article 344 of the EPA violations of ban on marketing or re-use of substances posing particular environmental threat, i.e. asbestos, $\mathrm{PCB}$ and other specified in the Order of the Minister of Environment of 9 December 2003 on substances posing particular environmental threat (Journal of Laws, No 217, item 2141) is penalized. Provided criminal penalties are alternatively: arrest, imprisonment and fines.

Pursuant to article 345 of the EPA, liability for an offence shall be borne by a subject obliged by law to treatment or disposal of an installation or equipment which are or have been used for substances posing particular environmental threat or for which there is a reasonable suspicion that such substances have been used. Applicable penalties are: arrest, imprisonment or a fine.

Article 346 of the EPA provides criminal liability for not communicating at determined periods information about a type, quantities and locations of substances posing a particular environmental threat, to a governor, commune head, city mayor or president, that is the statutory obligation (section 1), and section 2 of article 346 of the EPA penalizes breach of the obligation to document a type, quantity and location of environmentally hazardous substances and a way to eliminate them. The penalty provided for both offences is a fine.

Pursuant to article 347 of the EPA, liability for the offence shall be assigned to a subject who markets plastic disposable dishes and cutlery (section 1) and other plastic products (section 2) not including information about their negative impact on the environment. The penalty for this offence is a fine. 
The provision of article 348 section 1 of the EPA constitutes liability of a subject that violates the prohibition specified in the Order of the Minister of Economy and Labour of 28 December 2004 on products covered by the obligation to provide information relevant to environmental protection (Journal of Laws of 2005, No 6, item 40), concerning marketing of products not conforming to the requirements listed in implementing regulations referred to in article 69 section 1 of the EPA. According to article 348 section 2 of the EPA the liability can be alternatively assigned to a vendor of such a product responsible for not providing information relevant from the viewpoint of environmental protection at place, or for not making a list of selected products on the market specified in the Order of the Prime Minister of 29 April 2004 on lists of relevant environmental information about products (Journal of Laws, No 98, item 999) available. The penalty for both offences is a fine.

Article 349 section 1 of the EPA criminalizes a failure to comply with statutorily defined duties of measurement with regard to operation of roads, railway lines, tram lines, airports, ports. In article 349 section 2 of the EPA liability for not fulfilling obligations arising from specific administrative decisions is provided. In both cases, the offences are punishable with a fine.

Article 350 of the EPA penalizes non-compliance by a person managing specific objects with the obligation to submit to competent authorities measurements results (section 1), as well as the obligation to submit (every 5 years) an acoustic map of the site where operation of road, railway line or airport may cause outpass of permissible noise levels in the environment. The penalty for committing offences indicated in article 350 of the EPA is a fine.

Article 351 of the EPA penalizes operating an installation that causes introduction of gases or dust into the air, sewage to water or soil and waste generation, without a required permit or in violation of its terms (section 1 ), or operating an installation without bringing security of claims from negative consequences in the environment required by an administrative decision (section 2). The list of penalties for these offences is diverse and includes the penalty of arrest, imprisonment and fine. Article 351 of the EPA provides criminal liability for disclosing information obtained in connection with the performance of activities of the environmental verifier. The penalty for this offence is alternatively imprisonment or a fine. By contrast, article $351 \mathrm{~b}$ of the EPA gives the basis for liability of an individual, representing an organization, who, not being competent to do so, uses identifications 
Teresa Mróz, Ewa Katarzyna Czech, Ewa Kowalewska-Borys

of participation in the national eco-management and audit system (EMAS). The legal consequence of this offence is a fine.

Article 352 of the EPA imposes on everyone who notices a failure, under pain of a fine, the obligation to notify without delay persons staying in the danger zone and an organizational unit of the State Fire Brigade or a commune leader, mayor or city president.

According to article 353 of the EPA, a person liable, under an administrative decision issued by the voivodeship environmental protection inspector in case of a failure, ordering conduct of appropriate research on the causes, course and consequences of the failure, imposing prohibitions or restrictions on the use of the environment, who does not perform duties ordered by the decision, is punishable. For committing this offence an alternative penalty of arrest, imprisonment or a fine may be predicated.

The provision of article 354 of the EPA obliges an operator of an establishment of increased or high risk, under pain of arrest, imprisonment or a fine, to notify the establishment to the competent authority of the State Fire Brigade and to create programs to prevent major industrial failures (section 1), and to perform information activities set in this provision in case of a failure (section 2).

The provision of article 355 of the EPA penalizes enumerated acts of an operator managing an establishment of high risk associated with the security system (in the broad sense) that guarantees the protection of people and the environment. The penalty list for these offences is diverse and includes a penalty of arrest, imprisonment and a fine.

Article 356 of the EPA provides liability for the offence of changes in operations of a high risk plant that may impact on an occurrence of industrial failure risk, without obtaining an approval of these changes from the regional commander of the State Fire Brigade in a security report, which is punishable with such penalties as: arrest or imprisonment or a fine. The same penalties are provided for the offence in the provision of article 357 of the EPA, according to which, liability of a subject that made the change in increased risk plant operations that may impact on an occurrence of an industrial failure risk, without submitting changes to the program of failure prevention to the powiat commander of the State Fire Brigade and to the voivodeship environmental protection inspector.

Article 358 of the EPA determines penalties for failure to comply with the obligations imposed by an administrative decision of the voivodeship commander of the State Fire Brigade in connection with location of clusters 
of plants with increased or high risk of likely to increase the possibility of an industrial failure or deepen its effects - mainly due to types, categories and quantities of hazardous substances being concentrated.

Article 359 of the EPA provides, under pain of a fine, criminal liability for non-compliance with the statutory obligation to keep records containing information on, generally speaking, the use of the environment and emission data (section 1) and for a failure to timely submit the mentioned above list to the voivodeship marshal.

The provision of article 360 of the EPA penalizes failure to perform the indicated administrative decisions whose common feature is the fact that they constitute a negative consequence of specific acts relevant in administrative law. In other words, the liability for this offence is a result of failure to perform an administrative decision, which, in turn, is a consequence of an offence generating risk to the environment. For committing the offence as the alternative penalty of arrest, imprisonment or a fine may be predicated.

\subsection{Conclusions}

In conclusion, it should be noted that repressive liability for acts which are hazardous or causing damage to the environment is multi-faceted. The Polish legislator establishes sanctions in the form of liability for petty offences regulated by the CPO and the EPA as well as liability for the offences specified in the PC. Therefore, it seems justified to inquire about a comprehensive regulation of all offences against the environment in one single act, i.e. in the EPA. However, it appears that this is not a solution that could be a postulate de lege ferenda, since the purpose and nature of the offences codified in the EPA is unique. Nonetheless, most solutions adopted by the legislator are controversial and raise justified doubts, particularly in terms of their practical use. The most important of them are: very broad objective scopes of subjects' liability (e.g. article 330 of the EPA), the simultaneous presence of criminal liability (e.g. article 331 of the EPA) and administrative liability (e.g. article 365 of the EPA), illusory liability for offences due to the lack of appropriate regulations (e.g. article 332a of the EPA), indeterminacy of the subject liable for an offence (e.g. article 336 of the EPA), blanket provisions regulating liability for an offence (e.g. article 338 of the EPA), dependence of liability for offences on provisions of local 
law (e.g. article 338 of the EPA) and the existence of a final administrative decision (e.g. article 353 of the EPA).

\section{Administrative liability in environmental protection}

Administrative liability is still the leading liability, on the base of which the Polish legislator is to protect environmental resources. It is caused by at least two circumstances. First of all, administrative aspects of the method is regarded as one which properties have the greatest potential regarding environmental protection. Secondly, it should be emphasized that the functions satisfy different types of liability. According to the position expressed in the science of law referring to functions of criminal, civil and administrative, liability, the following pattern must be indicated. Although with regard to the types of liability compensation, preventive and even repressive objective are involved, criminal liability is mainly repressive, in the sphere of civil liability the compensation function is the leading one. In the area of administrative liability the preventive function plays a prominent role ${ }^{5}$.

Given the nature of the legal good, i.e. the environment, it is to be assumed that the preventive function of the legal solutions (including liability) protecting it is the most desirable. This is due to the fact that the affected elements of the environment will not always be possible to be restored to its original state, therefore, the caused damage will be irreversible. At the same time being aware of the fact that elements of the environment remain in close relationships with one another, it must be assumed that causing damage which is not possible to eliminate (by the natural restitution) to one of its element may lead to adverse changes in other components. The situation and above-mentioned legal environment justify the leading position of administrative liability in environmental protection ${ }^{6}$.

It should be considered desirable in regard to administrative liability to go beyond confirming the thesis that the primary criterion for inclusion of particular legal structures in the framework of administrative liability

5 W. Radecki, Odpowiedzialnośc prawna w ochronie środowiska, Warsaw 2002, p. $82-83$.

6 E. K. Czech, Szkoda w obszarze środowiska i wina jako determinanty odpowiedzialności administracyjnej za tę szkodę, Bialystok 2008, p. 37. 
is a conviction that everything that does not clearly belong to the sphere of civil, criminal or employee liability should be regarded as belonging to administrative liability. This position, as noted in the science of law, is justified by views expressed in this regard in the literature. At the same time, it is stressed that this is a good criterion, but sufficient to create an independent structure of administrative liability, having a creative importance for the shape and content of future legislation or future practice in environmental protection. It is, therefore, postulated to extract other criteria associated with moving the focus from negative approaches, which science of administrative law still cannot effectively resist ${ }^{7}$.

The Polish law science has created numerous definitions of administrative liability in environmental protection. The framework of this study make it impossible to present their full catalogue. Seeing the significant contribution which each of them has brought to the development of environmental law, the following position should be indicated. According to it, administrative liability in environmental protection is to be understood as the regulated by law possibility to start legal measures implemented in administrative forms and procedures in relation to a particular entity. It is a result of entity's activity violating the condition of the environment ${ }^{8}$.

While defining the scope of administrative liability in environmental protection its two areas should be indicated. The first of these structures is determined in articles 362-375 of the EPA. The second area is formed by provisions of the Act on Damage. This normative system provokes controversy that will be given below only as an example.

\subsection{Administrative liability in the provisions of the Environmental Protection Act - selected issues}

Under the Environmental Protection Act, the basic regulations in the field of administrative liability have been included in articles 362-375. In the science of law, in the area of these regulations, the catalogue of measures that according to the legislator's will are to implement administrative liability were distinguished. Among them the following means are listed ${ }^{9}$ :

\footnotetext{
7 J. Boć, K. Nowacki, E. Samborska-Boć, Ochrona środowiska, Wrocław 2008, p. 386.

Ibidem, p. 388.

Ibidem, p. 390-391.
} 
Teresa Mróz, Ewa Katarzyna Czech, Ewa Kowalewska-Borys

- imposition of the obligation to reduce the environmental impact and reduce the risk (through an administrative decision - article 362 of the EPA);

- imposition of the obligation to restore the proper environment to the appropriate state (through an administrative decision - article 362 of the EPA);

- imposition of the obligation to pay the amount of money that corresponds to the amount of damages resulting from breach of the environment to the budget of a relevant local governments (possibly more relevant municipal budgets in proportion to the size of the damage, in the situations mentioned in article 362 section 4 of the EPA - note of the author), in situations where there is no possibility of imposing a duty to take action, as defined in article 362 of the EPA (through an administrative decision);

- to require an individual to reduce negative impact of installations (through an administrative decision - article 363 of the EPA), (in accordance with current legislation, imposed, by an administrative decision, to an individual whose activities affect the environment negatively the obligation to execute operations in order to reduce the negative impact on the environment within the specified time - note of the author);

- cessation of activities threatening life or health of people (by a decision of a provincial environmental protection inspector - article 364 of the EPA);

- suspension of use of an installation operated without a required integrated permit or in violation of the conditions laid down by law (under a decision - article 365 of the EPA);

- determining (in an administrative decision) the date of infringement removal, alternatively after suspension of the installation in the circumstances set out in article 367 of the EPA;

- suspension of use of an installation (under an administrative decision), in the situations mentioned in article 368 of the EPA;

- prohibition of manufacturing, importing, marketing of products that do not meet requirements of environmental protection (by a decision of the provincial environmental protection inspector - article 370 of the EPA);

- demand to remove infringements or suspend the use (or launch - the author's note resulting from a change in the legal status), installation 
in case of industrial failure risk (by a decision of the competent authority of the State Fire Brigade - article 373 of the EPA).

On the basis of Section III of the EPA 'Administrative Liability', the view has been expressed that the standards contained therein provide for two forms of administrative liability, i.e. administrative remedy, as well as 'detailed forms of suspension of activities threatening the environment'.

Other members of the judiciary point mainly to three measures, which authorized bodies may use to carry out this liability. The basis for their use are unlawful acts, but not necessarily at fault. In the group there are fines (for violating environmental regulations), cessation of activities threatening the environment and other sanctions, particularly quasi-indemnity ${ }^{10}$, but not of the civil damages nature ${ }^{11}$.

It should be emphasized that within the provisions of Section III of the EPA two of the three specific measures have been settles, i.e. the cessation of actions threatening the environment and the mean of quasicompensation. The third of the measures i.e. a fine is a subject to the regime of provisions of article 298 and the following of the EPA.

The group of institutions carried out by means of administrative liability should also include increased fees referred to in article 292 of the EPA, constituting part of an administrative penalty for not having a license required by law. The Supreme Administrative Court' resolution of 21 December 1998 issued by seven judges ${ }^{12}$ rightly stated that introduction of pollutants into the air by an organizational unit for which the emission quota has not been established in a decision, was an administrative tort. The imposition of an additional fee, which should be distinguished from the fee for actual introduction of pollutants into the air as an increased fee, on an organizational unit was an administrative sanction for not having a license required by law, in spite of an existing ban introducing pollutants into the air. Such behaviour resulted in violating this prohibition.

10 The term of "quasi-indemnity" is used by W. Radecki, op. cit.., p. 68-69.

11 Podział został przytoczony za: D. Maśniak, Ubezpieczenia ekologiczne, Kantor Wydawniczy Zakamycze, Zakamycze 2003, p. 43.

12 The Supreme Administrative Court the resolution issued by seven judges of 21 December 1998, N OPS 13/98 ONSA of 1999 Vol. 2, item 46. 
Teresa Mróz, Ewa Katarzyna Czech, Ewa Kowalewska-Borys

\subsection{Administrative liability in the provisions of law on the prevention of environmental damages and their repair - selected issues}

The entry into force of the Act of 13 April 2007 on the prevention of damages to the environment and their repair ${ }^{13}$ resulted in significant changes in the existing structure of administrative liability in environmental protection. This caused the need for a new approach to administrative liability in genere ${ }^{14}$. Under the normative act the Directive 2004/35/EC of the European Parliament and the European Council on environmental liability with regard to the prevention and remedying of environmental damage ${ }^{15}$ was transposed into the Polish law. Despite the ongoing discussion among the legal environment on the type of liability governed by the provisions of the Act on Damage, most representatives of the science of law expressed the opinion that the act has standardized administrative liability. It has been also indicated that the liability has strong links to the civil law, and, due to that, the achievements of the doctrine and judicature formed on the basis of the civil law relations should be applied to legal institutions such as fault or causal relationship ${ }^{16}$.

In determining the conditions of liability regulated by the Act on Damage it is prerequisite to refer to the key article 2 of this normative act. While defining the determinants, which condition the occurrence of administrative liability for environmental damage and the state of imminent threat of damage, several categories of situations can be perceived. The following ones should be pointed out:

- causing an imminent threat of environmental damage or damage to the environment by activities of an entity benefiting from the environment which pose a risk of damage to the environment,

- causing an imminent threat of environmental damage or damage to the environment by activities of an entity benefiting from the environment,

13 The Act of 13 April 2007 on the prevention of damage to the environment and its repair, Journal of Laws, No 75, item 493, with subsequent amendments.

14 E.K. Czech, op. cit., p. 271.

15 The Directive 2004/35/EC of the European Parliament and the European Council on environmental liability with regard to prevention and remedying of environmental damage, OJ 2004, L 143/56, hereinafter Directive 2004/35/WE.

16 E.K. Czech, op. cit., p. 140 and the following, and the works cited there. 
other than to a risk of damage to the environment, when they involve protected species or protected habitats and occurred at fault of the entity benefiting from the environment,

- eventually, when the adverse effects were caused by diffuse emission, originating from many sources, an entity will be responsible if it is possible to establish a causal relationship between the direct threat of environmental damage or damage to the environment and activities of the entity benefiting from the environment.

The construction of liability specified in the provision of article 2 allows to distinguish administrative liability in environmental protection, which premises is the fault (article 2 section 1 point 2 of the Act on Damage). The wording of art 2 section 1 of the Act on Damage provoked divergent opinions on the liability specified therein. It is indicated that strict liability is presented there ${ }^{17}$. In some views it is pointed out that the regime of objective liability was used in the regulation ${ }^{18}$. It was also noted that the liability on the basis of the indicated act is characterized by some specificity. Article 9 of the normative act determines that in the event of environmental damage or imminent threat of such damage, the user of the environment is obliged to take specific actions. The provision of article 2 in conjunction with article 6 point 9 indicates that these obligations lie with entities benefiting from the environment. Under article 22 section 2 the Polish legislator introduces the possibility of not paying costs of preventive and remedial action by a user, if the circumstances defined in this regulation occur. The disputable issue is whether the rules shall exempt an entity benefiting from the environment from the obligation to carry out preventive and remedial action or only from incurring costs of these activities ${ }^{19}$.

Taking a certain position on this matter affects the possibility of recognizing that the Polish legislator described the conditions of liability exemption in article 2 section 1 point 1 . It does not affect the assumption that it is a model of strict liability.

17 B. Rakoczy, Komentarz do ustawy o zapobieganiu szkodom w środowisku i ich naprawie, Warsaw 2008, p. 20.

18 W. Radecki, Ustawa o zapobieganiu szkodom w środowisku i ich naprawie. Komentarz, Warsaw 2007, p. 49.

19 E. K. Czech, Odpowiedzialnośc niezależna od winy za szkody w środowisku i stany bezpośredniego zagrożenia nimi w relacji do obowiązku ponoszenia kosztów dziatań zapobiegawczych $i$ naprawczych, in: Odpowiedzialnośc za szkodę w środowisku, B. Rakoczego ed., Toruń 2010, pp. 96-97; see also the discussion presented therein. 
Teresa Mróz, Ewa Katarzyna Czech, Ewa Kowalewska-Borys

Referring to the conditions for liability based on the principle of fault, as well as independent of fault, the following observations should be underscored.

With regard to the issue of the damage evidence, under the current law, showing any difference in damage under administrative liability is possible in case of damage within the meaning of the civil law. Taking into account the factors, it should be noted that damages that can be distinguished on the basis of article 24 section 1 of the Act on Damage are closer to socalled classical damage within the civil law meaning than to damages in the environment as a common good, referred to in article 24 section 2 .

The damages referred to in article 24 section 1 are damages related to the property of an entity, as opposed to damage to the environment as a common good. The latter damages involve tangible and intangible goods occurring outside of individual rights. Article 6 point 11 of the Act on Damage limits the scope of the damage indicated in both cases, not involving bodily injury to a person. In the regulation the damage to the environment is determined as negative, measurable changes in the state or functioning of natural elements only, such as protected species, protected natural habitats, water or surface of the earth. This position seems accurate referred to the legal definition of repair of natural elements, given in article 6 point 8 of the Act on Damage. It has been indicated that the repair of natural elements, regarding all the listed natural elements, takes the form of a removal of threats to human health. The provision of section 2 of the Order of Minister of Environment of 30 April 2008 on the evaluation criteria of damage in the environment ${ }^{20}$ should also be pointed. It is stated that the damage in the environment occurs if a change of state or functioning of natural elements has a measurable negative effect on human health. The damage to the environment, under the regulation implementing this act, is always connected with a detriment to a person as a measurable, negative effect or function of changes in the natural elements for human health. It is debatable whether the connections imply that damage to the environment is also damage to a person, especially in the context of the first definition of article 6 point 11 of the Act on Damage. There is no doubt that the repair of damage to the environment is expected to overcome risks to human health. The Polish legislator, however, does not

20 The Order of Minister of Environment of 30 April 2008 on the evaluation criteria of damage in the environment. 
comment whether it involves repairing the consequences of a measurable, negative effect on human health. The view according to which the regime of the Act on Damages covers damage to person is controversial under the applicable law. It is more justified to assume that repair of damage to the environment leads to elimination of risks to human health and, therefore, the state of threat of damage to person ${ }^{21}$.

The scholar achievements of the legal environment allow to express the view that the two types of damage distinguished on the basis of article 24 of the Act on Damage may take the form of damnum emergens. It is not quite clear if they cannot appear in the form of lucrum cessans. The fact that the damage to the environment involves a negative, measurable change in the function of natural elements can justify such a possibility. In accordance with article 6 point 6 of the Act on Damage these elements should be treated as the usefulness of protected species, protected natural habitats, ground water or other natural or human elements. The regulations of the Act make it impossible to determine whether the extent of damages include lost profits, lost by a particular entity and by 'anyone'22.

Turning to the issue of fault, however, the existence of numerous controversies related to its determination should be indicated. The achievements of the science of law lead to the conclusion that the transfer of the theory of fault developed on the basis of the civil law regulations to the grounds of administrative and legal solutions creates a problem. It can be illustrated by the concept of illegality in terms of traditional administrative law and civil law. It can be demonstrated in case of the objective-subjective theory of fault, as well as in the situation when it is recognized that illegality is only a premise of fault. Liable entities not only exceptionally conduct activities based on a license causing damage to the environment. The possibility to adopt the doctrine of illegality within the meaning of civil law will bring numerous problems in those cases where parties will lead the indicated activities in accordance with terms of a license. The existing problems cannot be solved by a secondary claim for a compensation from public authorities, e.g. for an unlawful act or nonfeasance in the exercise of public authority. The liability of collective entities is also an issue emerging problems ${ }^{23}$.

21 E.K. Czech, Szkoda w obszarze środowiska i wina..., p. 273 and 274.

22 Ibidem, pp. 274-275.

23 Ibidem, p. 280. 
Teresa Mróz, Ewa Katarzyna Czech, Ewa Kowalewska-Borys

The question of the causal relation as a condition to bear particular liability as determined in the Act on Damage is characterized by a high degree of complexity. The framework of this study, as in the previous two conditions, allows only to signal numerous problems existing in the application of the law regulating damage. Article 2 of the Act, invoked above in the text, enables to assume that the legal construction, which is used by the Polish legislator on the basis of the civil law, with regard to the requirement of the existence of the causal relation, is also applied in the area of the regulation of the Act on Damage ${ }^{24}$. In the civil law doctrine it is stressed that the essence of the causal relation as a basis for liability is the condition that an incident and damage remain in relation to each other which allows the conclusion that the one element of the relation is a result of the other. This requirement is included in provisions of special regulations, which determine the obligation to remedy. The rule is that the regulations are designed in such a way that apart from the necessity of an event ('reason') and damage to occur, it is indicated that between these elements an objective link should occur ${ }^{25}$. For legislative reasons, the situations, when a claim arises based on the mere fact of damage, regardless of what was the cause of that damage, should be treated as of an exceptional nature. It should be noted that the legislator in some provisions, for example in article 438 or article 846 section 1 of the $\mathrm{CD}$, provides only a general description of elements of factual states, but does not point to any specific facts that could be considered to cause damages ${ }^{26}$.

In the body of the $\mathrm{CC}$ the legislator does not use only one language method in any particular consistent way to express the requirement of an objective link between the damage and the event which forms the basis for the obligation for compensation, and this may occur, for example, by a description of facts indicated in a provision concerning liability ${ }^{27}$. It is therefore possible to assume that, despite some differences in content, in all three cases under the regime of article 2 of the Act on Damage, there is a requirement of an objective relation between the damage and the event.

24 See for further details: E.K. Czech, Zwiqzek przyczynowy - przestanka ponoszenia odpowiedzialności za szkody w środowisku.

25 S. Garlicki, Odpowiedzialność cywilna, p. 87, see: A. Koch, Metodologiczne zagadnienia zwiazku przyczynowego w prawie administracyjnym, Poznań 1975, p. 86.

26 Ibidem, pp. 86 and 87.

27 Ibidem, p. 87. 
Liability in Environmental Protection Regulations... - Part Two

Moreover, the wording of those provisions determine the need to presume the existence of this relation ${ }^{28}$.

The fact that the concept of 'the causal relation' was used only in the provision of article 2 section 2 of the Act on Damage may raise doubts. Such a construction would indicate that the causal relation is a prerequisite of liability solely on the basis of those specific situations, with the exception of the category of cases specified in article 2 section 1 of the Act on Damage. It must be assumed that the wording of article 2 section 2 provides a similar structure to the one used in the article 478 of the CC (where the liability for casus mixtu is regulated $)^{29}$. In jurisprudence it is recognized that these are cases where the legislator expressis verbis requires the conditio sine qua non test to be applied in order to determine the presence or absence of a causal relation. The exemption from the obligation to compensate damage will occur when there will be no causal relation between the damage and activities of an entity ${ }^{30}$. The construction existing in the norm of article 2 section 2 of the Act on Damage justifies the conclusion that the Polish legislator could assume such the conditio sine qua non relation in situations referred to in article 2 section 2 of the Act on Damage. It is difficult to adopt the view on the matter in an unambiguous way because of the wording of the abovementioned regulations $\mathrm{s}^{31}$.

The fourth prerequisite condition for administrative liability for environmental damage is the event causing the damage. The interpretative guidance regarding the conditions were included in the articles 2 and 3 of the Act on Damage. The Polish legislator differentiates categories of events that cause environmental damage and states of imminent threat of damage, depending on the criterion of damage occurrence in certain elements of the environment. The events are defined as an activity of an entity benefiting from the environment which poses a risk of damage to the environment (which was mentioned in the text of article 3 of the Act on Damage) and other activities of an entity benefiting from the environment. It should be emphasized that regarding protected species or protected habitats the

28 Cf. E.K. Czech, Zwiqzek przyczynowy - przestanka...; The ruling of the Tribunal, Case C-378/08.

29 Ibidem.

30 A. Koch, Metodologiczne zagadnienia zwiqzku przyczynowego w prawie administracyjnym, Poznań 1975, p. 75.

31 E.K. Czech, Zwiqzek przyczynowy-przestanka... 
Teresa Mróz, Ewa Katarzyna Czech, Ewa Kowalewska-Borys

legislator adopted a catalogue of events that cause such damage broader than in the case of damage done to water and earth's surface. In the Act on Damage there have been provided exceptions from this set of cases conditioning liability, e.g. in article 4 of the Act.

\section{Concluding Remarks}

In terms of administrative liability in environmental protection the area of questions disputed by the legal environment covers a wide range of issues. The key issues were signalled above, as crucial ones from the standpoint of analysis of this legal institution. The scope of discussion on particular issues is dependent on the degree of controversy, and the criterion of temporal functioning of the regulations in Polish legal system.

Concluding considerations of administrative liability in environmental protection the following problem should also be indicated. The relationship between the Act on Damage and the EPA creates problems of interpretation. In this area an important standard is contained in article 7 of the EPA. According to this regulation, for environmental damage the provisions of Act on the prevention of damage to the environment and its repair shall be applied. Language interpretation of, as well as systemic and functional of the provision of article $7 \mathrm{a}$ of the EPA entitles to express the conclusion that not provisions of the EPA but of the Act on Damage shall be applied to the imminent threat of damage to the environment and damage to the environment. Determination of the relation between provisions of the two appointed normative acts in the relationship of lex specialis - lex generalis is possible due to article 7a of the EPA in a general way pointing to the object of the regulation and excluding application of the standards the Environmental Protection $\mathrm{Act}^{32}$. In the science of law, the relationship between the laws within the normative in the area of liability for environmental damage, indicating its disputability, has been questioned $^{33}$. It should be emphasized that listing standards in article $7 \mathrm{a}$

32 E.K. Czech, Szkoda w obszarze środowiska..., p. 196, see also the discussion presented there.

33 B. Rakoczy, in: J. Ciechanowicz-McLean, Z. Bukowski, B. Rakoczy, Prawo ochrony środowiska. Komentarz, Warsaw 2008, p. 57. 
in Title I 'General Provisions', Section I 'Scope of the Act' of the EPA does not entitle to take a firm position that the standard applies only to exemptions in the field of administrative liability. Such positioning of this provision permits the adoption of an exemption of the EPA provisions broader than only in relation to rules governing administrative liability. It should also pointed that the role of the norm of article 15 section 4 of the Act of Damage is incomprehensible. In science of law, it is reasonably indicated that because of the exclusion of application of article 362 of the EPA to the states covered by the hypothesis of article 15 section 1 of the Act on Damage, on the basis of the latter of the analysed acts, the possibility of recognizing that taking preventive and remedial action is impossible has been excluded. The cases of obligating subjects using the environment to pay an appropriate amount (or amounts) to certain entities were eliminated ${ }^{34}$. But it cannot be not noticed that the exclusion of application of article 362 of the EPA to damage to the environment (within the meaning of the Act on Damage) was made in genere on the basis of article $7 \mathrm{a}^{35}$.

The so defined legal status must be perceived as unfavourable. It should be treated this was, as a rule. Protection of a legal interest such as the environment additionally reinforces this position.

34 W. Radecki, Ustawa o zapobieganiu szkodom ws śodowisku i ich naprawie. Komentarz, Warsaw 2007, p. 89.

35 E.K. Czech, Szkoda w obszarze środowiska..., s. 197 and 198. 